\title{
Modern Pedagogy and the Ratio Studiorum*
}

\author{
Ziba Ahmadian \\ University of Toronto, Toronto, Canada
}

\begin{abstract}
This presentation discusses the requests of modern pedagogy, and a possible bridging between the traditional teaching strategies drawn by the Ratio Studiorum of a unique and rare structure, and today's learning process. It will argue the practical application and philosophy of education widely accepted and recognized as a part of curricular activities within the learning environments, though with no recognition of its origin. This paper aims to examine the indisputable contributions of the educational methods of the Jesuits in our time, although, the discipline has developed new fundamental, and new concepts such as self-esteem, self-awareness, and self-determination among others.
\end{abstract}

Keywords: the Ratio Studiorum, Jesuits curriculum, Jesuits pedagogy, Jesuits self-esteem

\section{Introduction}

This presentation illustrates how the Ratio Studiorum (1599) that is the official plan for Jesuit education, in 16th century laid the principles of the curricular activities. The history of education in Europe confirms that education for the young has been offered by priests, whom made their services available to the higher class, royals, rich, and professionals such as administrators, or physicians. Researchers such as Knowles ${ }^{1}$ have agreed and admitted that until recently the only one model about learning and the characteristics of learners dominating secular schools was the 12th century Universities of Bologna ${ }^{2}$ and Paris $^{3}$. In his The Modern Practice of Adult Education, From Pedagogy to Andragogy (1970), Knowles recognizes the remarks by the monks in teaching very young children mostly reading and writing throughout Europe and North America and much of the rest of the world, especially by missionaries in the 18th and 19th centuries. Though, the recognition of curricular activities set by the Ratio Studiorum in modern pedagogy is nowhere to be found.

In this presentation, firstly and briefly, we will take a look at the first Jesuit's college established in Sicily in 1548, and will observe the learning practices within the Jesuits school.

The author will then introduce the Ratio Studiorum, and explain how it came to the existence.

In conclusion we will look at the modern pedagogy and new concepts in learning process, and the Jesuits practices.

\footnotetext{
* Ratio atque Institutio Studiorum Societatis Iesu (1599) that is “The official plan for Jesuit education”. Ziba Ahmadian, Ph.D. in Italian Studies, Department of Italian Studies, University of Toronto.

1 For a complete review see Knowles (1970).

2 University of Bologna was founded in 1088.

3 The foundation date of the University of Bologna can be established between 1160 and 1250 .
} 


\section{The First Jesuits' College}

The importance of the education for St. Ignatius ${ }^{4}$ brought some scholars to believe that the Society of Jesus was founded merely to teach the catechism to the children and illiterates. When Ignatius of Loyola submitted the Formula Istituti (1538), that is the document containing society's founding principles, to the Pope Paul III (1468-1549), he approved and recognized the duties of Jesuits, as O’Malley (2006) explains “by works of charity, and specifically by the education of children and unlettered person in Christianity" (p. XXXV). The Ratio Studiorum itself asserts the great importance of the education for the Fonder of the Society; as first article of "Rules for Provincial”", emphasizes that as "The final goal of the Society's studies” (Pavur, 2005, p. 7). First equip the members with a good education and other skills, and then provide them with the opportunity to share the fruit of their training with others whether in classroom or elsewhere.

While preaching and teaching of catechism was the key command of the Society, soon Ignatius had to face a real problem which was training of his own men. One of his companion, Laynez ${ }^{6}$ suggested him to open some houses in the cities where universities are located. This would facilitate young Jesuits to study properly. By 1544 there were seven of these houses in Europe. Meantime, some schools had been opened as well. The schools were a huge success, especially when in 1546 Ignatius allowed the school in Gandìa to offer the human science courses also to non-Jesuits. The success of this move was beyond belief.

Though, the greatest achievement reached when the first Jesuits College was founded in Messina. In 1548 St. Ignatius of Loyola decided to send Father $\mathrm{Nadal}^{7}$ to open and see the first Jesuit school in Sicily. Father Nadal arrived in Messina on April 8, 1548. Already a couple of weeks later on April 26 the lessons began with classical languages, grammar, rhetoric, and dialectic. The summer gave Jesuits' brothers the time needed to get organized. The program, a circular letter on the school itself, and the curriculum for the next academic year were prepared. This was the first plan and the first bulletin ever prepared and distributed for a Jesuit school, in which was clearly indicated that the methods of the University of Paris would be followed.

From the very first day the Fathers observed any progress or any short come, and this was reported to Rome. After almost two years, in 1551 a second plan was ready to replace the first one. Father Nadal prepared the program having in mind the best of renaissance humanistic ideals and the methods of Paris; it was again circulated among Jesuits colleges that already had spread in Italy and other countries in Europe. Father Nadal laid the base of a phenomenal pedagogical program extremely efficient for the education of the members of the Society. It was not only aimed to shape the students' character, and to strengthen faith in them, but also to secure in their heart love for teaching, as the "Rules for Rector" clearly indicates:

[75] Interest in education

1. The Society eagerly undertake secondary and higher education so that Jesuits can be properly instructed both in doctrine and in the other matters that contribute to helping souls, and so that they can share with their neighbours what they themselves have learned. Therefore, after his rightly foremost concern for religious and essential human virtues, he should devote himself especially to achieving, with the help of God, this final goal that the Society has set before itself in allowing schooling to be part of its mission. (Pavur, 2005, pp. 30-31)

\footnotetext{
${ }^{4}$ Ignatius of Loyola (1491-1556), founder of the Society of Jesus (1541).

${ }^{5}$ There are only a few editions in English of Ratio Studiourm: The Jesuit Ratio Studiorum of 1599 (Farell, 1970); Principles of Jesuit education in practice (Donnelly, 1934); The Ratio Studiorum (1599). For our study, the last edition of the volume has been chosen and all our references are made to this volume.

${ }_{7}^{6}$ Diego Laynez (1512-1565).

7 Jerónimo Nadal (1507-1580). On Jerónimo Nadal, see: Bangert (1992).
} 
Meantime, in Rome Fathers were to receive notes and letters from colleges and missionaries all over the world. They were meticulously to collect the information, classify them and examine every single aspect of the progress of the students and teachers within their mandates. Ignatius informs the principals that "no rule of studies was to be considered fixed or final until a program applicable to all the schools could be drafted and approved” (Pavur, 2005, p. 218).

\section{The Ratio Studiorum}

The continues practice and reflections, led by classics, St. Thomas theology, Aristotle, and the practical method of the University of Paris became the model for the Jesuits to draft and develop a unique and universal pedagogical structure for their college. The new method was arranged with a set of rules and regulations for principals, professors, administrators, and students to assure not only the order and studies, but also to guarantee the respect for students, to distinct, and to differentiate between the capabilities and potential of each student. The presence in the classroom, and abundance of the exercises were also extremely emphasized.

The Ratio atque institutio studiorum Societatis Iesu that is the Official Plan for Jesuit Education, issued in 1599 was the result of over 50 years of academic efforts, years of collaboration, committee work, and experience in Jesuit schools all over the world.

It provided Jesuits with the first uniform method to teach and to train the teachers. It allowed the members to use their mother tongue and the local language to learn some material such as mathematics and science, nonetheless Latin was the dominant language in the college; the students were expected to master in classical languages such as Greek and Hebrew as well. The Jesuits substituted supervision for compulsion and dissociated punishment from teaching. They also introduced a procedure to promote abler students to a higher grade after only half a session. They maintained their sever practices in sacramental confession and communion, case of conscience, moral, and religious matters.

The plan also was to educate the best preachers, professors, scientists, mathematician, philosophers, writers, and artists. It meant to discover talents and to prepare the members for the highest executive positions in the society, in commerce, in finance, or any form of cultural activities. Not to mention how this plan was successful in view of the time, and the battle between the Catholic Church and Protestantism.

What distinguishes The Radio Studiorum from other orders is the fact that Fathers of the Society of Iesu tried, for the glory of God, to faultlessness of their pedagogical rules. With no limitation, or internal barrier they drafted a program that would not be inflexible. They were perfectly aware of weak points hidden in the text, or unthinkable. Just so, open to the outcomes, for years the drafts were put into practice, and the results and the progress of students were carefully assessed. Finally after years of study, research and observation, since the original draft had been prepared, the first text of the Ratio Studiorum was approved and released to the print. The final text of the Ratio Studiorum, though, was no longer the imitation of the University of Paris, nor Quintiliano's Institutio oratoria (circa 39-Roma c. 95).

As Scaglione (1986, pp. 82-83) point outs the Ratio Studiorum, was the distillation of the Jesuit educational experience in Italia, specifically Roman climate of the late 16th century.

James Dominic, Secretary of the Society, with his “Letter of Transmission” (Farrell, 1970, pp. xii-xiii) (see Appendix) dated January 8, 1599, explains clearly the procedures of the preparation of the Ratio Studiorum.

Soon after the publication of the Ratio Studiorum, some colleges in Europe argued about its originality. Farrell (1970) in his The Jesuit Ratio Studiorum of 1599 indicates: 
[...] When the early Jesuit schools began to spread from Italy, Spain and Portugal to France and Germany, claims were made by several headmasters of rival schools, especially by Johann Sturm, headmaster at Strassburg, that the Jesuits had copied their pedagogical practices. As a matter of fact, however, when the manuscript of Quintilian's Institutio Oratoria was discovered at St. Gall by the humanist Poggio in 1410, Quintilian soon became the favourite source of most of the school programs in the late fifteenth and early sixteenth centuries at Liege, Strassburg and elsewhere. This was prior to the opening of the first Jesuit school. Ignatius of Loyola and his early followers, on the other hand took as their chief authority the University of Paris, their Alma Mater. Their preference for Paris resulted from their interest, at that time, in the practice rather than in the theory of education. The University of Paris undoubtedly absorbed a great deal of its pedagogy from Quintilian or from humanist adaptations of Quintilian, but it had reduced these ideas to order and to practice. [...] (pp. ix-x)

In his work Farrell divides the Ratio Studiorum in four principal areas: (1) Administration by defining the function, interrelation, and duties of such officials as the provincial, rector, and prefects of studies; (2) It outlines a curriculum by placing their proper sequence and gradation courses of study in theology, philosophy, and the humanities; (3) It sets forth in detail a method of conducting lessons and exercises in the classroom; and (4) It provides for discipline by fixing for the students norms of conduct, regularity, and good order.

Let us just take a look and see how the Ratio Studiorum is structured. The Ratio Studiorum is divided into 40 chapters, and each chapter into many subchapters forming 527 articles in total:

\author{
[H1] Rules of the Provincial \\ [H2] Rules for the Rector \\ [H3] Rules for the Prefect of Studies \\ [H4] Common Rules for All the Professors of the Higher Faculties \\ [H5] Rules for Professors of Sacred Scripture \\ [H6] Rules for the Professor of Hebrew \\ [H7] Rules for the Professors of Scholastic Theology \\ [H8] Catalog of Some Questions \\ [H9] From the First Part of Saint Thomas \\ [H10] From the First Part of Part II \\ [H11] From the Second Part of Part II \\ [H12] From Part III \\ [H13] On the Sacraments in General \\ [H14] On Baptism \\ [H15] On the Eucharist \\ [H16] About Penance \\ [H17] On Matrimony \\ Rules Resumed \\ [H18] Rules for the Professor of Cases of Conscience \\ [H19] Rules for the Professor of Philosophy \\ [H20] Rules for the Professor of Moral Philosophy \\ [H21] Rules for the Professor of Mathematics \\ [H22] Rules for the Prefect of Lower Studies \\ [H23] Regulations for Taking Examinations \\ [H24] Regulations for Prizes \\ [H25] Rules Common to All the Professors of the Lower Classes \\ [H26] Rules for the Professor of Rhetoric \\ [H27] Rules for the Professor of Humanities \\ [H28] Rules for the Professor of the Highest Grammar Class \\ [H29] Rules for the Professor of the Middle Grammar Class
}


[H30] Rules for the Professor of the Lowest Grammar Class

[H31] Rules for Jesuit Students

[H32] The Training of Those Who Are Reviewing Theology in Private Study for Two Years

[H33] Rules for the Teacher's Assistant, or the Beadle

[H34] Rules for Non-Jesuit Students

[H35] Rules for Academies

[H36] Rules for the Prefect of an Academy

[H37] Rules for the Academy of Theologians and philosophers

[H38] Rules for the Prefect of the Academy of Theologians and Philosophers

[H39] Rules for the Academies of Rhetoricians and Humanities Students

[H40] Rules for the Academy of Grammar Students

(Pavur, 2005, pp. xiii-xxiii)

What we are discussing in this paper refers mainly to the chapter 39 "Rules for the Academies of Rhetoricians and Humanities Students”, article 513 to 519. That is the part Farrell considers the method of conducting lessons and exercises in the classroom.

Already Father Nadal's program - later approved in the Ratio Studiorum engaged students in the actual work of the classroom, while looking for specific and practical pedagogical guidance. Every activity had its own distinctive spirit and purpose, and as we mentioned, later was subjected to prolonged testes and experience.

These activities are quite familiar to all of us; the learning circle, and classroom activities from primary education to secondary, from post-secondary and further up, to organizing conferences, presentations, declamations and theatrical performances to boost students' self-esteem, and burst their talent and artistic skills were all a part of curricular activities prescribed by the Ratio Studiorum. Students' performance and participation in classroom, group activities, sharing ideas, and writing together were then, and are today a part of recommended exercises for the members.

According to the Ratio Studiorum-Article 356 Special exercises-“Special exercises were to cultivate not only the students' memories but also their intellectual talents”.

Articles 514 and 515 [H 39] “What exercises are to be held by moderator”, respectively read:

[514] [...] Just as he (moderator) judges the time to be right, the moderator will at some times give lessons or present questions on some chosen material or author; or at other times, he will give some rather unfamiliar rules for speaking taken from Aristotle, Cicero, or other rhetoricians; or again at other times, he will quickly cover some author and ask the members of the academy questions about that material; and at other times, he will set them problems to be solved, and the like.

[515] [...] sometimes they should engage in speeches for the prosecution and for the defense in turn, with the moderator's approval; sometimes they should present classes, with at least two in disputation against the presenter; sometimes they should defend thesis, arguing in a manner that is more oratorical than dialectical; sometimes they should fashion emblems and insignia on some designated subject matter, sometimes inscriptions or descriptions; sometimes they should contrive riddles or solve them; sometimes they should practice invention one at a time, coming up with loci to support a proposed theme, whether on the spot or after some study time; sometimes they should practice elocution by suiting figures of language or thought to the material that has been found; sometimes they should sketch dialogs, poems, or tragedies; sometimes they should imitate a whole oration by an illustrious orator, or a poem by a famous poet; sometimes they should construct certain symbols, in such a way that they produce their own sayings about a single topic that has been proposed for everyone individually; sometimes, after the books of some author have been distributed, they should each produce sayings or phrases gleaned from it. Finally they should practice whatever usually gives rise to eloquence and is produced by it. (Pavur, 2005, pp. 211-212) 
Roberto Marzano ${ }^{8}$ cofounder and CEO of Marzano Research Laboratory in Centennial, Colorado differentiates instruction and uses inquiry as well as the application. Marzano claims that the child develops information-processing skills, such as attention, memory capacity, and learning strategies. Teachers can help students develop their capacities for formal thinking by putting the students in situations that challenge their thinking and reveal the shortcomings of their logic. Siegler's ${ }^{9}$ (2002) approach is called "rule assessment" because it focuses on understanding, challenging, and changing the rules that students use for thinking.

Anderson's research (Reznitckaya \& Anderson, 2006, pp. 175-198) identified 13 forms of talk and argument that helped manage the discussion, get everyone to participate, present and defend positions, and handle confusion. The researchers found that the use of these different forms of talking and thinking snowballed-once a useful argument was employed by one student, it spread to other students, and the argument stratagem form appeared more and more in the discussion. He also proved that open discussions-students asking and answering each other's questions-were better than teacher-dominated discussion for the development of these argument forms. According to Educational Psychology (2009) over time, these ways of presenting, attacking, and defending positions could be internalized as mental reasoning and decision making for the individual students. In fact what Educational Psychology focuses on is different strategies to develop students' analytical thinking and to supply them with argumentation skills. In recent years, enormous amount of research has been dedicated to designing new methods purposely to assess classroom interactions, and evaluating the outcomes to finally adopt, quiet unknowingly, the Jesuits strategies within the learning environment.

The recent studies confirm the importance of activity and constructing knowledge. Piaget's (1964) fundamental insight was that individuals construct their own understanding; learning is a "constructive” process. At every level of cognitive development, you will also want to see that students are actively engaged in the learning process. In his words:

Knowledge is not a copy of reality. To know an object, to know an event, is not simply to look at it and make a mental copy or image of it. To know an object is to act on it. To know is to modify, to transform the object, and to understand the process of this transformation, and as a consequence to understand the way the object is constructed. (p. 8)

In Jesuit colleges the goal was “Ad perfectam enim eloquentiam informat” (Ratio Studiorum, 1599, p. 155) ${ }^{10}$ that is "an education in perfect eloquence"; in other words preparing the base for the eloquence. The goal was reached by teaching Latin, Greek, and Hebrew while using constantly the Latin language. The students became masters in writing and speaking perfectly Latin, attending lectures on rhetoric. At the completion of studies, the student was already a maestro, a doctor, a teacher, or a professor in every sense. Mental faculties, intellectual capacities, habits, order, precision, imagination, comprehension, implementation, awareness, and other psychological qualities will be developed only if the student abandons the listener passiveness and participates actively in classroom activities creating with his own words what he is taught, translating and creating with his own imagination from his own experience some beautiful poems, phrases, or paragraphs, rivaling the model proposed in the classroom. As a method, once this phase was over, the Jesuits were endeavoring to critique and

\footnotetext{
${ }^{8}$ Robert Marzano is cofounder and CEO of Marzano Research Laboratory in Centennial, Colo., and a former senior scholar at Mid-continent Research for Education and Learning in Aurora, Colo. He has developed programs and practices used in K-12 classrooms that translate current research and theory in cognition into instructional methods.

9 See also Siegler $(1976,1981)$.

${ }^{10}$ [H26] Regulae professoris Rhetoricæ, [375] Gradus.
} 
evaluation. The best compositions in all forms of poetry and prose had to be rewarded. Since art is a skill, and skill is acquired through repetition, practice must dominate the classroom. The student must be constantly writing, reading, and speaking, so that simultaneous use of the five senses, along with imagination, sensibility and determination generate a unique piece of art.

In 2005, Gredler argued that this active experience, even at the earliest school level, should not be limited to the physical manipulation of objects. It should also include mental manipulation of ideas that arise out of class projects or experiments. In fact, Jesuit plan focuses on abundant exercising and memorizing. Learning of different languages, mandatory use of Latin during all activities, continuously exercising, writing compositions, preparing oral presentations, declamations or imitation of an eminent poet or author were only a part of practices in Jesuits learning environment. These activities, as Vygotsky ${ }^{11}$ calls them "imitative learning tools", aside from providing the adequate amount of practice on a specific subject, were a real encouragement for the student who was, consequently, praised by the professor and colleagues.

According to Vygotsky there are at least three ways in which cultural tools can be passed from one individual to another: imitative learning (where one person tries to imitate the other), instructed learning (where learners internalize the instructions of the teacher and use these instructions to self-regulate), and collaborative learning (where peers strive to understand each other and learning occurs in the process) (Tomasello, Kruger, \& Ratner, 1993, pp. 495-552). Vygotsky was most concerned with instructed learning through direct teaching or through structuring experiences that support another's learning, but his theory supports other forms of cultural learning as well. Assisted learning, or guided participation in the classroom, requires scaffolding-giving information, prompts, reminders, and encouragement at the right time and in the right amounts, and then gradually allows the students to do more and more on their own. Teachers can assist learning by adapting materials or problems to students', demonstrating skills or thought processes; walking students through the steps of a complicated problem, doing part of the problem. Though, sometimes, the best teachers are other students who have just understood a particular concept. These "teachers" may be engaging in reciprocal teaching. This is exactly what Jesuits were doing.

In 1990, Marsh proved that students with superior self-esteem (Rosenberg, Schooler, Schoenbach, \& Rosenberg, 1995) are more successful in school. In addition, scholars confirm that higher self-esteem is related to better approach toward school, more positive behavior in the classroom, and greater popularity with other students. ${ }^{12}$

So, what should schools do to promote students' self-esteem? ${ }^{13}$ (Woolfolk, 2009, pp. 85-86). So far more than thousands of books, and articles on how to boost students' self-esteem have been published and schools and mental health facilities continue to develop self-esteem programs. In 1991, Beane argues self-esteem and the school's role in "enhancing self-esteem, and if so on what grounds and to which extent" (p. 25). He states the attempts to improve students' self-esteem have taken three main forms; personal development activities such as sensitivity training, self-esteem programs where the curriculum focuses directly on improving self-esteem; and structural changes in schools that place greater emphasis on cooperation, student participation, community involvement, and ethnic pride.

\footnotetext{
11 On Vygotsky see: The Collected Works of Vygotsky (1987) and The Essential Vygotsky (2004).

12 See also Reynolds (1980) and Metcalfe (1981).

13 On “What should schools do to encourage students' self-esteem?”, see Chapter 3 Personal, Social, Emotional Development in Educational Psychology (2009).
} 
For that many views have been revealed superficial, money-making, and packed with trendy observations, the self-esteem has become a serious issue for study and critics. Though beyond the feel-good psychology of some aspects of the self-esteem concept is a basic truth: "Self-esteem is a central feature of human dignity and thus an inalienable human right", Beane (1991) argues, "schools and other agencies have a moral obligation to help build it and avoid debilitating it” (p. 28). Practices that allow genuine participation, cooperation, problem solving, and accomplishment should replace procedures that damage self-esteem. The Ratio Studiorum seriously concerns about the students and teachers dignity, as for many articles refer directly to virtues, talents, awards, encouragements, etc.: articles such as "Virtue ought to be taken into account" (p. 26), "Talent ought to be taken into account, and" (p. 29), "How a decision about talents should be made” (p. 36), "Diversity according to the diversity of locales” (p. 72), "promotion to rank” (p. 17), "Special and General Acts” (pp. 106-107), public exercises, weekly, and monthly open disputations, etc., Articles 517 and 518 respectively read:

[517] It is worthwhile to have some of the more impressive of these exercises (such as the lessons, declamations, and defenses of theses) presented especially by the rector of the academy, occasionally with some formal ceremony and before a circle of guests.

[518] sometimes private awards can be given to those distinguishing themselves in composition or recitation or in solving riddles and problems. Likewise, the more formal awards can be distributed to all the members together once a year whether on the basis of a grant, or according to whatever scheme the rector of the college likes.

More than 100 years ago, "William James (1890) suggested that self-esteem is determined by how 'successful' we are in accomplishing tasks or reaching goals we value. If a skill or accomplishment is not important, incompetence in that area doesn't threaten self-esteem” (Backley, 2012, p. 71; Woolfolk, Winne, Perry, \& Shapka, 2009, p. 86). Students must have success on tasks that matter to them. But the way individuals explain their successes or failures is also important. For the students to build self-esteem, they must learn to attribute their successes to their own efforts, not to luck or to special assistance. Teachers' evaluations, comments, advice or criticism, grading practices, and praising can make a difference in how students feel about their abilities in particular subjects. The growth of the intellectual capacity, judgmental autonomy, reasoning, imagination, attention, selection, evaluation, expression, and so on—if in one hand can flourish and bring to mental development of the student, in the other will precipitously cause fatigue and the collapse of the student. Jesuits soon discovered that the only remedy for such exhaustion was encouragement in form of public praise to the student. Experience shows that the praise is the most effective way to improve student's ability and therefore classroom work. The public - in this case, the applause of classmates, teachers, and school officials - will not only be the most important motivation, but it will also be of immense comfort to the student's exhausted soul. Within the curricular activities of Father Nadal readings, of especially the compositions in the classroom, followed by the declamations in the college at the beginning and at the end of the academic year, aimed to encourage students in public, saving his soul, stimulating his confidence and self-esteem.

But the greatest increases in self-esteem probably come when students grow more competent in areas they value-including the social areas that become so important in adolescence. Thus, a teacher's greatest challenge is to help students achieve important understandings and skills, and that is exactly the curriculum and practices set by the Ratio Studiorum. 


\section{Conclusions}

Without a doubt, in recent years the educational programs have progressed significantly. Scholars, researchers, and experts have constantly worked and continue to work to develop new strategies enriching learning methods. The pedagogy, the science of education, in terms of training of teachers and teaching of students, curricular activities, class setting, and the whole learning environment is improving without stop. Hence, this paper intends to recognize the strong link between the Jesuits' practices set by the Ratio Studiorum and the educational practices defined by various scholars in modern time. The paper indicates that the teaching techniques which require direct participation of students in different activities intended to encourage students to enhance learning, to provide access to educational opportunities, or to create learning environment were mostly implemented by Jesuits and had been in use long before they could be considered as conditions external to the learner's success: skills, performance, practice methods, modelling, coaching, reflecting, creating, exploring, evaluation, and feedback, etc.. From this point of view, the profound influence of the Jesuits' practices on the educational system in our time cannot be denied. An in-debt look to the today's educational norms will find some of these practices unchanged and perhaps unchangeable through time.

\section{References}

Backley, P. (2012). Motivation and self-esteem. Learning in early childhood (pp. 65-79). London: SAGE Publications.

Bangert, W. V. (1972). A history of the society of Jesus. St. Louis: The Institute of Jesuit Sources.

Bangert, W. V. (1992). Jerome Nadal, S. J. 1507-1580 (edited and completed by T. M. McCoog). Chicago: Loyola University Press.

Beane, J. (1991). Sorting out the self-esteem controversy. Educational Leadership, 49(1), 25-30.

Brodrick, J. (1940). The origin of the Jesuits. London: Longmans Green and Co Ltd..

Cathrene, M., Connery, V., John-Steiner, P., \& Marjanovic-Shane, A. (2010). Vygotsky and creativity: A cultural-historical approach to play, meaning making, and the arts. New York: P. Lang.

Conwell, J. F. S. J. (2003). Walking in the Spirit (A reflection on Jeronimo Nadal's phrase“Contemplative likewise in action”). Saint Louis: The Institute of Jesuit Sources.

David, L., \& Fleming, S. J. (1996). Draw me into your friendship: A literal translation \& a contemporary reading. Saint Louis: The Institute of Jesuit Sources.

De Aldama, A., Antonio, M., Bottereau, G., Gioia, M., Dumeige, G., Dezza, P., \& González, L. (Eds.). (1977). La formula dell'Istituto, S. J (The formula of the Institute). Roma: Centrum Ignatianum Spiritualitatis.

Dixon-Krauss, L., \& Plains, W. (Eds.). (1996). Vygotsky in the classroom: Mediated literacy instruction and assessment. N.Y.: Longman.

Donnelly, F. P. (1934). Principles of Jesuit education in practice, 1869-1959. New York: P.J. Kenedy \& Sons Publishers.

Donnelly, J. P. (Ed. \& Trans.). (2006). Jesuit writings of the early modern period 1540-1640. Indianapolis: Hackett Publishing Company Inc..

Farrell, A. (1970). Introduction. The Jesuit Ratio Studiorum of 1599 (pp. I-XIII). Washington, DC: University of Detroit.

Frawley, W. (1997). Vygotsky and cognitive science: Language and the unification of the social and computational mind. Cambridge, Mass.: Harvard University Press.

Freedman, S. W. (1994). Crossing the bridge to practice: Rethinking the theories of Vygotsky and Bakhtin. Berkeley, CA: National Cetrer for the study of writing, University of California; Pittsburgh, PA: National Center for the Study of Writing, Carnegie Mellon University.

Gredler, M. E. (2005). Learning and instruction: Theory into practice (5th ed.). Boston: Allyn and Bacon.

Knowles, M. S. (1970). The modern practice of adult education: Andragogy versus pedagogy. New York: Association Press.

Marsh, H. W. (1990). Causal ordering of academic self-concept and academic achievement: A multiwave, longitudinal panel analysis. Journal of Educational Psychology, 82(4), 646-656.

Metcalfe, B. (1981). Self-concept and attitude toward school. British Journal of Educational Psychology, 51, 66-76.

O’Malley, J. W., Bailey, G. A., Harris, S. J., \& Kennedy, T. F. (Eds.). (2006). Jesuits II cultures, sciences, and the arts 1540-1773. Toronto: University of T Press. 
Piaget, J. (1964). Development and learning. In R. Ripple, \& V. Rockcastle (Eds), Piaget rediscovered (pp. 7-20). Ithaca, NY: Corrnell University Press.

Reynolds, M. (1980). Self-esteen abd ckassriin behaviour in elementary school children. Psychology in the Schools, 17, $273-277$. Reznitskaya, A., \& Anderson, R. C. (2006). Analyzing argumentation in rich, natural contexts. Informal Logic, 26(2), $175-198$.

Ribble, R. E., \& Rochcastle, V. N. (Eds). (1964). Piaget rediscovered. New York: Ithaca.

Rieber, R. W., \& Carton, A. S. (1987). The collected works of L. S. Vygotsky (prologue by J. S. Bruner: Translated and with an introduction by Norris Minick). New York: Plenum Press.

Rieber, R. W., \& Robinson, D. K. (Eds.). (2004). The essential Vygotsky (in collaboration with Jerome Bruner (Selections, English, 2004)). New York: Kluwer Academic/Plenum Publishers.

Rosenberg, M., Schooler, C., Schoenbach, C., \& Rosenberg, F. (1995). Global self-esteem and specific self-esteem: Different concepts, different outcomes. American Sociological Review, 60(1), 141-156.

Scaglione, A. D. (1986). The liberal arts and the Jesuit college system. Amsterdam: John Benjamins Publishing Company.

Siegler, R., \& Chen, Z. (2002). Development of rules and strategies: Balancing the old and the new. Journal of Experimental Child Physiology, 81, 446-457.

Smith, L., Dockrell, J., \& Tomlinson, P. (Eds.). (1997). Piaget, Vygotsky and beyond: Future issues for developmental psychology and education. London: Routlege.

Ratio Studiorum (The official plan for Jesuit education) (Translated and Annotated by C. Pavur (2005)) (1599). St. Louis: The Institute of Jesuit Sources.

Tomasello, M., Kruger, A. C., \& Ratner, H. H. (1993). Cultural learning. Behavioral and brain. Sciences, 16, 495-552.

Vygotsky, L. S. (1971). The psychology of art. Cambridge, Mass.: M.I.T. Press.

Vygotsky, L. S. (1978). Mind in society: The development of higher psychological processes. M. Cole, (Ed.). Cambridge: Harvard University Press.

Woolfolk, A. E., Winne, P. H., Perry, N. E., \& Shapka, J. (2009). Educational psychology. Toronto: Pearson Canada.

\section{Appendix}

A comprehensive program for our course of studies began to take shape about 14 years ago. Work on it has now been completed and copies of its final form are being sent to the various provinces of the Society.

On account of its great potential value for our schools, our Very Reverend Father General had hoped that the program would have been completed and implemented long before now. This, however, proved to be impossible. The undertaking was so ambitious and was fraught with so many problems that it was felt to be unwise to put it in force until the provinces would have an opportunity to study its implications and suggest improvements. Father General decided that it would never do to impose a set of regulations on the whole Society until every effort had been made to insure willing acceptance on the part of all concerned.

The six priests to whom the task of formulating a program of studies was entrusted spent long and arduous years in research and discussion. They finally completed their work, and the results were forwarded to all provinces of the Society to be weighted and evaluated by our teachers and educational experts. These men were requested to examine the document for the purpose of noting and eliminating defects or of introducing improvements. They were then to make a report expressing their views on the plan as a whole and to explain the principles which supported these views.

All of the provinces cooperated eagerly and resolutely, and forwarded their criticisms and their suggestions to Rome. There the chief professors of the Roman College and a special committee of three Fathers edited these reports and submitted their findings to Father General. In conference with the Fathers Assistant, he carefully scrutinized the new version of the plan of studies, approved it, and forwarded copies to all the provinces with orders that it was to be scrupulously followed.

Father General reminded the Provincials that since new procedures to be reliable, must be tested in the light of actual experience, they should note the day-by-day results of the new plan and make a report to Rome. He himself would then be in a position to put the stamp of his final approval. 
When the Provincials came to Rome for the fifth General Congregation, they brought with them the memoranda of defects which daily experience in the classroom had detected in the second draft of the Ratio. The chief complaint was that the new plan was too cumbersome. Hence it was decided to face the huge task of reviewing the whole project. This required that the members of the Roman committee study the reasoning which prompted the various suggestions, that they ponder well what decision to make in each instance, and finally that they endeavor to reduce the whole document to smaller and more manageable dimensions. Finally the task was completed and we have good reason to hope that the final version will meet with the approval of all.

This revised edition of the Ratio which is now being sent out is to supersede all previous experimental editions and is to be followed faithfully by all members of the Society. It is therefore incumbent on all our teachers to carry out all its provisions. I am quite convinced that if the members of our Society realize how much this project means to our Father General, they will comply cheerfully with his wishes.

Since responsibility for the success of this Ratio Studiorum lies squarely on the shoulders of superiors, Father General urges them to make every effort to secure from their subjects ready and complete dedication to this program which breathes the spirit of our Constitutions and promises to be of untold advantage to our students. 